\title{
KINSHIP NETWORKS, LOCAL GOVERNMENT, AND ELECTIONS IN A TOWN IN SOUTHWEST GERMANY, 1800-1850'
}

\author{
Carola Lipp
}

\begin{abstract}
This article is based on the thesis that kinship structures were an important element of communal politics and were thus inscribed into the political system of even early constitutionalism. The investigation presented covers an important change in the political culture from the Ancien Régime to the modern constitutional state in southwest Germany, and it raises the question of whether election processes affected traditional structures of representation based on kinship relationships and the ascription of political competence to an elite of notables. The analysis of kinship networks within the city council and city deputation, however, comes to the opposite conclusion - that kinship networks survive even in a system where each year people were newly elected. The analysis of voters' alignments along kinship lines also demonstrates the power and persistence of kinship structures in the early nineteenth century and reflects the differences between kinship mobilization within agriculturally bound and urban artisan groups.
\end{abstract}

Keywords: political culture; early constitutionalism; constitutionalism; kinship; local elite; elite; Germany; social network analysis; social networks

Many kinship studies in historical cultural anthropology focus on the internal structure of families, households, and coresident $\mathrm{kin}^{2}$ and analyze kinship as a configuration with its own "meaning."” They are interested in strategies of marriage and social placement, in the formation of alliances through interlinking kin, and in the transmission of property in the form of dowries, patrimonies, and other forms of inheritance. ${ }^{4}$ Their

Carola Lipp is Professor at the Institute for Cultural Anthropology and European Ethnology at the University of Goettingen. Her major field is the study of political culture in communities and different social groups. Her research also includes structured network analysis, demographic methods, and gender-related approaches to culture. Her most recent publications deal with networks in complex societies and with civil society and political mobilization.

Please address correspondence to Dr. Carola Lipp, Institut für Kulturanthropologie/Europäische Ethnologie Friedländer Weg 2, 37085 Göttingen, Germany; Telephone: 0049-551-395352 (secretary), 5348 (office), Fax: 551-486647, E-mail: clipp1@gwdg.de or Carola.Lipp@t-online.de.

Journal of Family History, Vol. 30 No. 4, October 2005 347-365

DOI: $10.1177 / 0363199005278726$

(C) 2005 Sage Publications 
view of politics is restricted to regarding political power as deriving from these familial stratagems. They interpret kinship ties as a means to maintain and transmit economic, social, and political power within the net of relatives and therefore very often focus on the specific moral obligation of "primordial attachments." It is this inherent particularism of kin relations that makes "kinship organization appear antithetical to many social institutions in modern society."

The exclusive concentration on kin relations ignores the fact that the Western form of kinship is closely related to the idea of community. In the older political theory of the late eighteenth and early nineteenth centuries, contemporaries regarded families as the foundations of community. ${ }^{7}$ Citizenship was bound to a self-sustaining household, usually based on marriage. Western concepts of kinship and community therefore describe two different strategies: On the one hand the dispersion of kinspeople and family ties throughout the community is emphasized, and on the other hand it is a stated fact that kinship tended to concentrate wealth and power by linking kin in marriages with close relatives and thus reproduced oligarchical structures of power. Local studies give evidence that the latter phenomenon proliferated in the late early-modern period, primarily in the eighteenth century, when church regulations were more tolerant toward marriages of consanguinal kin. ${ }^{8}$

Usually kinship studies start with a family reconstitution and end in detailed descriptions of descendancy and individual kinship relations using complicated drawings of genealogical family trees. The project reported here took a very different route. The starting point was the analysis of revolutionary politics and local movements in 1848 , especially political configurations and political formation processes during the upheaval of 1848 and in prerevolutionary times (i.e., the so-called Vormärz). Our interest aimed at social substructures of political participation such as neighborhoods and workplaces and the influence of corporations or group affiliation. We investigated local associations and the building of political factions and parties and tried to identify the structure of social networks that created and emerged from these political events and interactions. ${ }^{9}$ In this context we also asked for the impact of kinship on local politics and widened our prosopographical approach to a complete reconstitution of all the town's families.

Peter Schweitzer ${ }^{10}$ once remarked that "what kinship does" might be important, not only the meaning of kinship. In light of an actor-centered theory of practice it might be more precise to ask "what do kin do together?" Kinship relations are practiced in daily living and social life as well as in the larger context of politics. The "culture of relatedness" ${ }^{11}$ should be observed in every form of social exchange and interaction. ${ }^{12}$

Normally kinship is mapped in a monofocal way looking from ego to ego's kinship links. Looking into the functions of kinship within the political system we designed a form of kinship analysis that could be used for the large corpus of a whole population and complex political groups. The data basis, built on nominal record linkage, contains - besides a large set of personal data-information about each person's political actions, from signing petitions to membership in associations, political institutions, corporations, and militia units. Also recorded is whether people were partisans of the new political factions during the revolution. Based on the parish registers we managed to establish a completely computerized family reconstitution of the whole population (1800-1860) that is linked to the above-mentioned political activities. Thus we have a huge social and political set of data that can be used to analyze political and social networks. ${ }^{13}$ 
In regard to communal titular offices and memberships in administrative boards and even in regard to liberal associations, kinship proved to be a very powerful element of political formation in early constitutionalism. Even in voters' decisions we could trace forces of kinship alignment. Our interest focused, therefore, on kinship configurations in local governmental institutions, and we concentrated especially on the function of kinship in the process of the historical transformation from the autocratic Ancien Régime into a constitutional system based on the election of community authorities.

Since 1819 the Wuerttembergian state was a constitutional monarchy with a representative body in the form of two chambers: one chamber, with budget rights and legislative power, was composed of elected members and the other was functioning as a house of lords. This dualism was reproduced on the level of community where a local council (Stadtrat) operated as executive. In regard to the budget and citizen-rights issues the executive was controlled by a deputation or committee of citizens (called Bürgerausschuss). ${ }^{14}$ In theory both organs were elected by those inhabitants who possessed the right of citizenship; in Wuerttemberg these were nearly 70 to 80 percent of the self-sustaining householders of a community. People who depended on poor relief were not allowed to vote.

The introduction of a fairly liberal constitution in the kingdom of Wuerttemberg in 1819 raises the question, did this new law and its succeeding ordinances have an effect on the traditional organization of communal power? As a curiosity in German constitutional law the Wuerttembergian constitution, for example, forbade for the first parliamentary chamber the coincidence of father-son memberships. On the communal level all direct first-degree relations on the agnatic and cognatic level were prohibited within the executive board, and since 1818 regular local elections were prescribed.

We wanted to know if and how the electoral system and its regulations interfered with the existing system of kinship networks and if traditional structures of representation changed with constitutional routines. Did kinship still remain an active factor of social and political integration in the early-modern state, at least on the local level? Our field of research is a town in southwest Germany: Esslingen, a formerly free imperial city, was annexed by Wuerttemberg in 1802. During the Vormärz it developed into one of the biggest industrial cities in the region, with 13,000 inhabitants.

As citizens of a free city, the inhabitants of Esslingen were used to self-government and the city had a long oligarchical tradition within senatorial ranks. Twelve years before Wuerttemberg took over there was a huge conflict in the city between citizens-mostly representatives of the artisanal corporations-and the city governing senatus or magistracy. Financial mismanagement and the exclusive practice of selfcooption were the central issues of the lawsuit brought before the Imperial Aulic Council (Reichshofrat). The city executive was organized according to two selecting principles, kinship ties and professional specialization. Because the magistrates (called senators) also served as justices, only people with an academic law education were allowed to enter the Inner Council, which recruited itself from the (male) members of the leading patrician families in town, whose sons were nearly automatically destined for political careers and acquired an education in respect to their future tasks. It is remarkable that the jurisprudential and administrational professionalism in the free city's government allowed even unmarried men to become part of the officecouncillor elite. Thus in Esslingen in 1790, three bachelors were members of the executive board. In the first part of the nineteenth century, when the magistrates started to 
be elected by the body of voters, this practice changed. Then only married men were chosen to become representatives because they better reflected the cultural expectations of the voting citizens whose status and right to vote was bound to household and marital status.

In the eighteenth century, the stronghold of power in the city was a tightly knit kinship network that changed during the constitutional rule in the nineteenth century. Unlike Wuerttemberg, where since 1758 community regulations kept close relatives out of the council (a precaution that resulted in the famous Vetterleswirtschaft, or regime of cousins, that dominated local politics, ${ }^{15}$ ), in the former free cities such restrictions were unknown. Consequently, in 1790, one-third of the magistracy in Esslingen were relatives of the patrician mayor, von Marchthaler, whose son, nephew, and son-in-law all served at the same time as members of the city magistracy. Together with another father and son and uncle and nephew constellation there were two pairs of brothers in service on the same board. Only two out of the fourteen acting patrician magistrates had no family relations to the other members of the magistracy. Based on close family ties, this system was nevertheless open to men from outside the city who had the juridical qualifications and were seen as suitable to marry into the inner circle of the local elite.

The example of Esslingen is not an exception: oligarchical structures among community executives were known throughout early modern times. ${ }^{16}$ It was a common phenomenon of free cities, where in the sixteenth century Emperor Karl V had established patrician regimes while simultaneously reducing the influence of artisans and corporations. At the end of the eighteenth century, in more than thirty of the fiftytwo free cities judicial conflicts arose ${ }^{17}$ in which citizens claimed their right to participation.

The state of Wuerttemberg put an end to this long smoldering conflict in Esslingen and replaced the overaged senators of the city's magistracy in 1803. Because the Wuerttembergian duke wanted to avoid high pension costs, most members of the newly appointed local government were recruited from the old administration; therefore, the change was less fundamental than the citizens' opposition had hoped. The seats of the magistracy were now- that is, at the beginning of the nineteenth centuryoccupied by an only slightly younger generation that still represented the old system and was still closely related to the former administrative elite. For example, two sons and one son-in-law followed their fathers in service. The newly appointed magistrates were given lifelong right to office and usually stayed there till they died. Until 1817 the magistrates still were self-co-opting and continued the habit of choosing successors of deceased councillors from the old families or among the judicially educated public servants. Anticipating the constitution in 1817/1818 the Wuerttemberg state united the members of the magistracy with those of the Outer Council of the former free city, a board on which mostly artisans and merchants served and which until then had only counseling functions relative to the executive board. For the first time representatives of these classes entered the local government and were also granted lifelong office.

The last of these executives, appointed in 1803 and 1817 on the mercy of the Wuerttembergian state, left the council late in March 1848 during the first days of the revolution, when mass protests drove them out. But two of those dismissed members immediately returned to office, having been (re-)elected by conservative voters in April 1848. Though the division in the city council during the years of the revolution of 1848-1849 reflected the rise of the new party system, the influence of kinship was not 


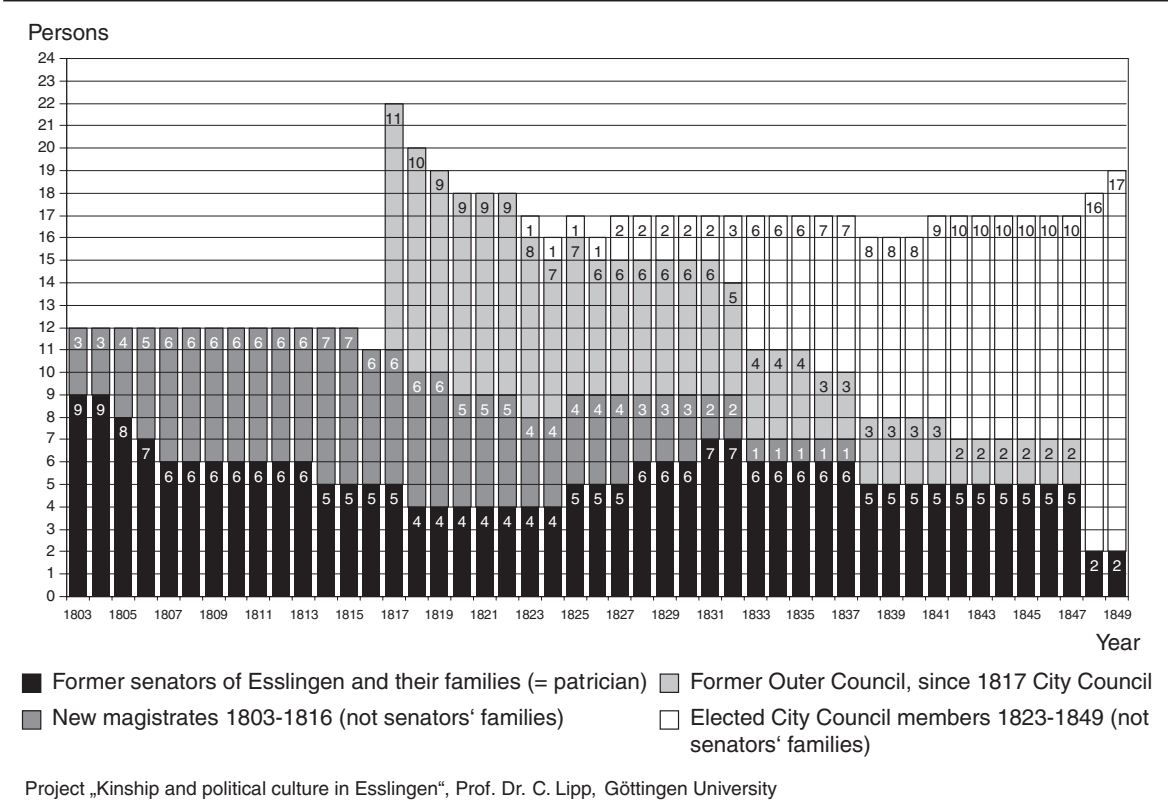

Figure 1. Members of the City Council with Patrician Background, Esslingen 1803-1849

completely replaced by that of political faction. The moral power of kin relations remained still virulent, and it is not surprising that in 1848 some of the more prominent successors in local authority were close kin to the departing former elite. For example, the mayor who was elected in 1848 was the grandson of one of the last mayors of the free city and the son of one of the old magistrates who was in service from 1803 to 1848. Other newly elected members were directly related to former council members. All mayors in the first sixty years of the constitutional nineteenth century were sons or nephews of former free city mayors. ${ }^{18}$ And this in a city that became famous for its democratic movement during the revolution.

Since 1803, when Wuerttemberg had nominated the first magistracy, it took twenty years till the first council member was freely elected by the citizens of Esslingen. And this renewal of the city's executive took place only because the old councillors began to die out. The long dominance of the traditional elite in Esslingen is demonstrated in Figure 1. From 1803 to 1817 the magistrates had the right of self-recruitment. In 1817 the members of the former outer council were added to the executive board and were guaranteed lifelong office. Only after 1823 a new generation entered the executive board. The result of the elections is rather astonishing. With one exception the men chosen by the Esslingen citizens between 1823 and 1835 were all descendants or close relatives of the leading patrician families of the Ancien Régime or relatives of the members of the old outer council of the free city. The citizens of Esslingen obviously considered the old elite families who were in power at the time of the free city, and even the representatives of the former outer council as particularly suitable and qualified to exercise local authority. ${ }^{19}$ Another reason for this choice might be the shaken selfimage of the annexed free citizens who kept close to their traditions and were thus opposing Wuerttembergian rules at the same time. 


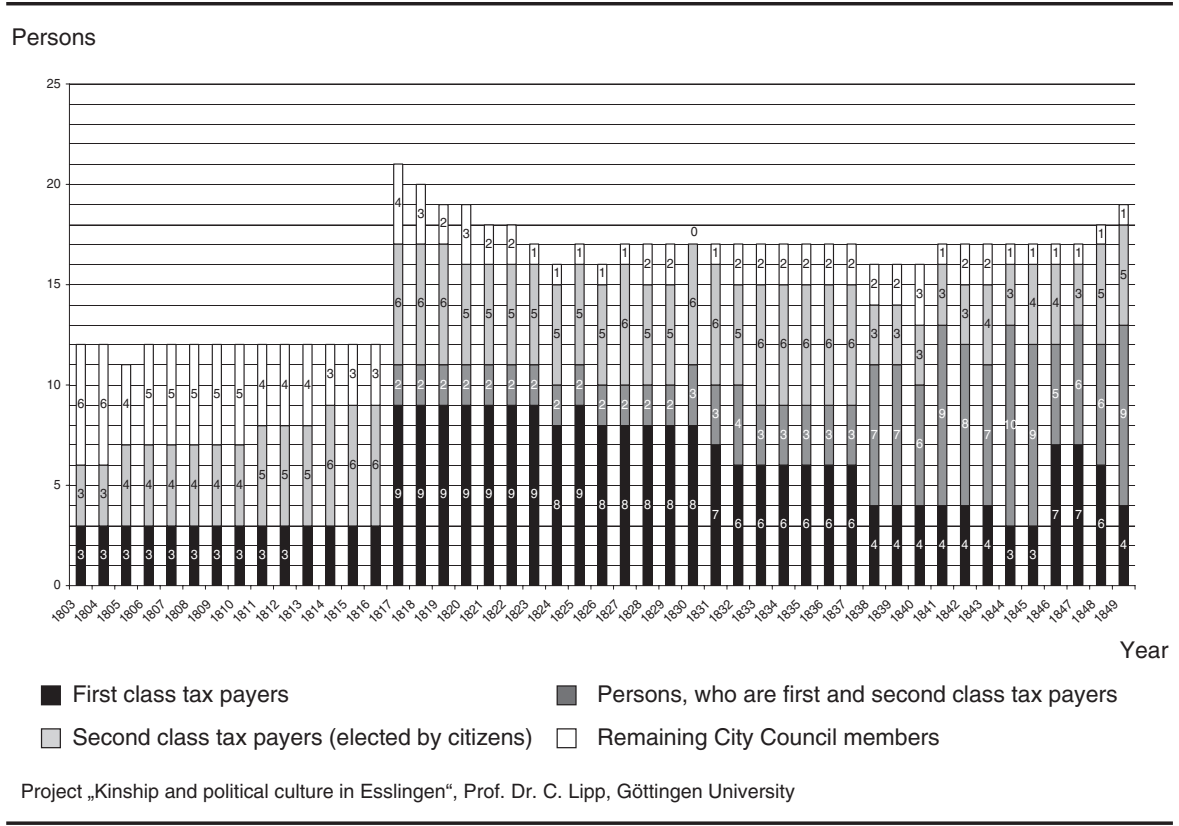

Figure 2. First- and Second-class Taxpayers in the City Council, Esslingen 1803-1829

There is no economic explanation for these election results. The position of the old elite was not founded on wealth —only a few of the magistrates of 1803 were wealthy enough to be among the first class of tax payers (see Figure 2). There were far more high-ranking tax payers among the members of the outer council and among the officials elected in 1840, when wealth became one of the selective criteria. Up to 1830 it was the implicit assumption of judicial competence, education, and longtime experience in governmental affairs that caused voters to choose representatives of these families. Tradition and kin attributes operated as charismatic symbolic capital ${ }^{20}$ that could be transformed into power even by election. As Wuerttembergian law did not allow first-degree kin to serve together at the city council, other strategies of representation became relevant, such as the building of chains, meaning that relatives followed each other in service and built a chain of kin that worked far more effectively and provoked less opposition and democratic reasoning than the old way of concentrating power in the hands of a few clans. Another strategy was the concentration on more distant affinal kinship. Self-co-opting councillors and, later on, the people who voted for them were more inclined to elect affinal kin of acting members and thus evaded the impression of the same names being represented within the council. ${ }^{21}$ The difference to the old, mostly agnatic-structured kin networks of the Ancien Régime now lay in its affinal structure and in the timing of membership.

If we look at the seventy-two members of the city council from 1803 to 1849 (see Figure 3), we find two grandfather-grandson relations, six sons who followed their fathers, and five successions between fathers-in-law and sons-in-law (of whom two were members at the same time). Another remarkable occurrence in the council was relations between co-fathers-in-law (eight relations); that is, parents who had managed to marry off their children to the children of a council colleague. There were six 


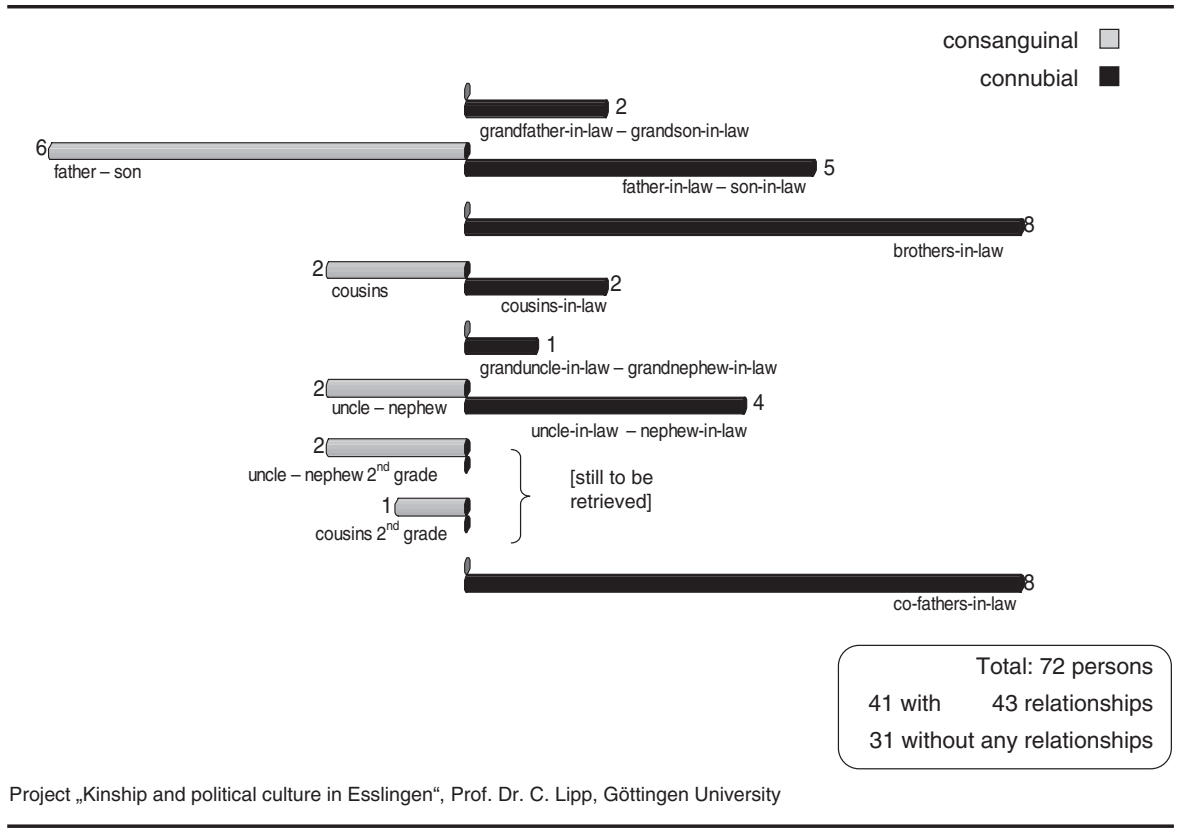

Figure 3. Kinship Relations Within the Esslingen City Council, 1803-1849

uncle-nephew relationships ${ }^{22}$ and seven couples of first cousins. Because Wuerttemberg forbade the simultaneous membership of fathers and sons, fathers-in-law and sons-in-law, and brothers and brothers-in-law ${ }^{23}$ but allowed the "spouses of several sisters to sit next to each other", connubial ties and kinship mediated through women were the political option of the time. Most of the kin relations (70 percent) in the council therefore were connected through connubial ties. On the affinal side we found eight brothers-in-law relationships among the office holders between 1803 and 1849, representing six magistrates who were in-laws related through the husbands of their spouses' sisters and five who were in-laws through their spouses' brothers. Two of them were in office at the same time. Forty-one people (forty-three if we count step relations) of the seventy-two were in some way related to each other. Of the thirty-one (if we subtract the stepfather and stepson it is only twenty-nine) men for whom we did not find kin relations, fifteen were connected with people in the second-mostimportant community board, the city deputation, and another four had relatives who were city officers in the formerly free city's administration. Because we have examined only the officeholders from 1803 to 1849 , and as our family reconstitution does reach very deep into the eighteenth century, we found only a small amount of grandfathergrandchildren successions. But we have the occurrence of a great-uncle and greatnephew relation and two uncle-nephew relations in second grade and also two second cousins who were all at one time or another members of the executive board of the city. Though some of the officers shared common ancestors (who were not council members) or were related as cousins (four relations), close kin relations in succession proved to be more frequent than the ties between first- and second-degree cousins. The famous Swabian Vetterleswirtschaft was actually practiced within a net of in-laws and political marriage alliances. ${ }^{24}$ 
Our exploration showed that in the first half of the nineteenth century the inner structure of the Esslingen council still followed kinship alignment principles. But instead of sharing office with relatives at the same time, the net of kinship ties was prolonged over time. Therefore there was no need to broaden the network to the extended kin, and the relationship between cousins played only a minor role and did not have the importance David Sabean demonstrated in the case of the Wuerttembergian village magistrates in Neckarhausen. The elite family net in the former free city Esslingen as a political enclave was far more closely intertwined than Sabean's findings about the village executive. ${ }^{25} \mathrm{Also}$, we can observe a clear distinction between the period of the free city and the constitutional phase. In the eighteenth century the circle of kin in administration was centrifugal and agnatic; consanguinal lines built the core of the city regime. In spite of the density of kin relations this system was able to include persons from outside via profession and marriage. During the nineteenth century there was an overall extension of family ties and a dominance of connubial or affinal kin networks. As a whole the system in the first half of the nineteenth century became in itself more exclusive because it tended to a strict form of local endogamy previously unknown to the old patrician elites who intermarried with patrician families of other free cities. In the nineteenth century fewer outsiders were elected to the city council and these few had to start their career by serving in the city deputation or in titular offices of associations for a long time. These findings suggest that the effect of kinship on community administration and city organization did not decrease but grew even more dense through a form of longtime multiconnectivity. The central element in these long chains of relatives was not patrilineal descent but a multiplex interlinking through marriage alliances.

Thinking in terms of kinship attributes and reflecting the quality of certain families were part of the notion of community. Therefore these ascriptions of familial competence were not limited to the powerful old governmental elites. Among the sixteen (later eighteen) elected members of the city deputation, that is, the board of representatives that had budget-control rights toward the executive, very soon oligarchical tendencies appeared. Although half of the board was elected anew each year, there evolved dense kinship networks and traditional patterns of political allocation (Figure 4).

We analyzed the outcome of thirty-three years of city deputation elections ${ }^{26}$ from 1817 to 1850 and found that there were at least two principles that ruled the choice of candidates. First, many of the elected citizen deputies belonged to the wealthier strata of the city and were first-rate taxpayers. With them a new economic elite entered the city administration, a tendency that can be observed in many of the German cities at that time. ${ }^{27}$ Second, we find a closely interwoven net of kin operating as representatives of the community. One-third of the city deputation (61 of 184) had no kinship ties with other members of the board. But of the majority of 123 persons each had on average 2 relatives within the citizen committee (so far we count 245 relations) and thus were multiply bound to each other. Relationships between brothers occurred 15 times; in 2 cases brothers even sat on the board during the same period of service. In 17 cases we found father-son constellations and 84 (!) uncle-nephew relations, 71 on the affinal side. Like in the executive council of the city the dominant ties were the least restricted connubial ones. Thirty-eight relationships between brothers-in-law can be observed between 1817 and 1849, most of them brothers of spouses and 27 brothers-in-law who had married the sister of the spouse of a board member. Among the members of the cit- 


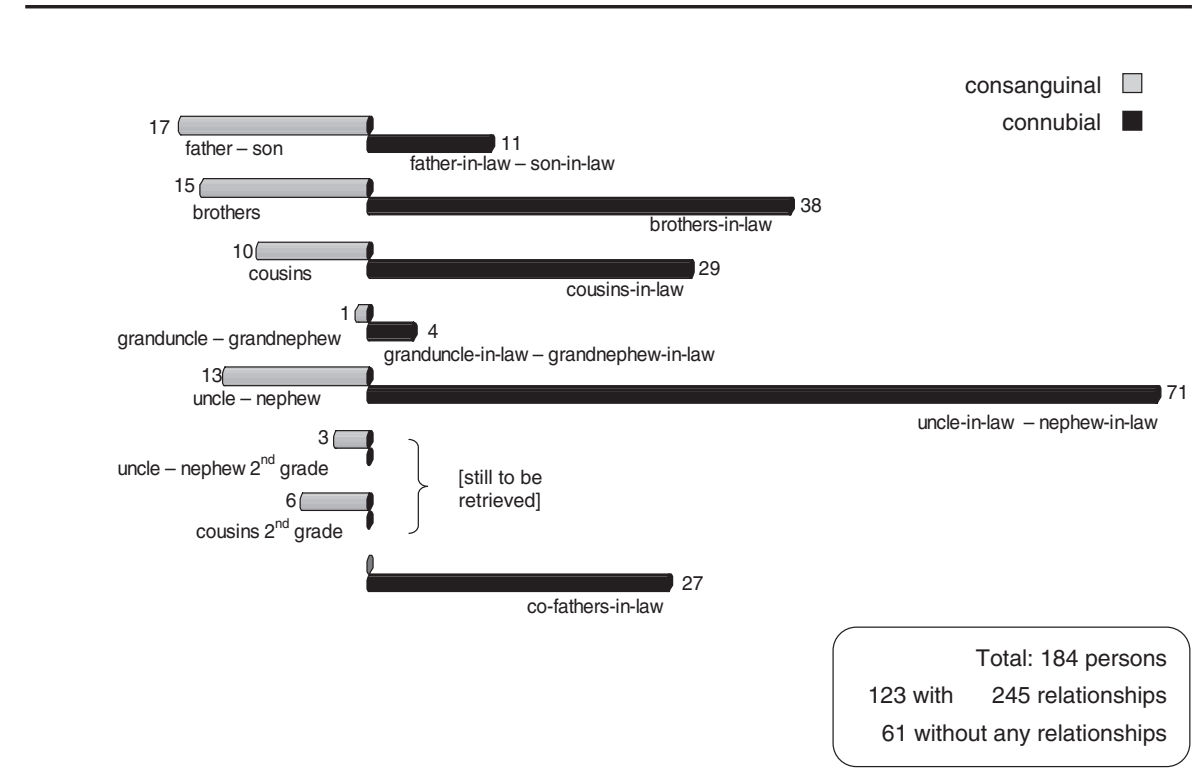

Project „Kinship and political culture in Esslingen“, Prof. Dr. C. Lipp, Göttingen University

Figure 4. Kinship Relations Within the City Deputation of Esslingen, 1817-1850

izen deputation we counted 11 relationships between fathers-in-law and sons-in-law, and obviously the arrangement of marriages between children occurred very often because we observed 27 couples of co-fathers-in-law who were at one time or another members of the board. The importance of connubial links is underlined by the fact that 29 of the 39 couples of first cousins were also related through marriage alliances. If we summarize all relationships built upon affinal bonds we find that affinal kin relations outnumber the consanguinal by 73 percent to 27 percent. It is also remarkable that the majority of the sixty-one persons who had no kinship relation within the deputation served for only one period while others were elected for two, sometimes even seven periods. ${ }^{28}$

Relevant for political communication in the city elite and of great influence on decision-building processes became the fact that kinship ties soon developed between the executive council and the citizen representation. Six sons of five council members and ten sons-in-law started their political careers in the citizen committee. Between council and deputation there existed seven relationships of brothers and twenty-eight of brothers-in-law; ten fathers-in-law and eighteen couples of co-fathers-in-law (fiftysix persons) guided the careers of their youths and twenty-eight uncles tutored their nephews. Thirty-two couples of cousins strengthened the existing ties in the second generation. These interlinking kinships were effective not only with regard to social advancement but also with regard to mediation between these structurally opposed organs of city politics. The fact that 106 persons of the representative board were related to city councillors contributed to the process of consensus building and appeased the structurally built-in rivalry of these two local governmental boards. 


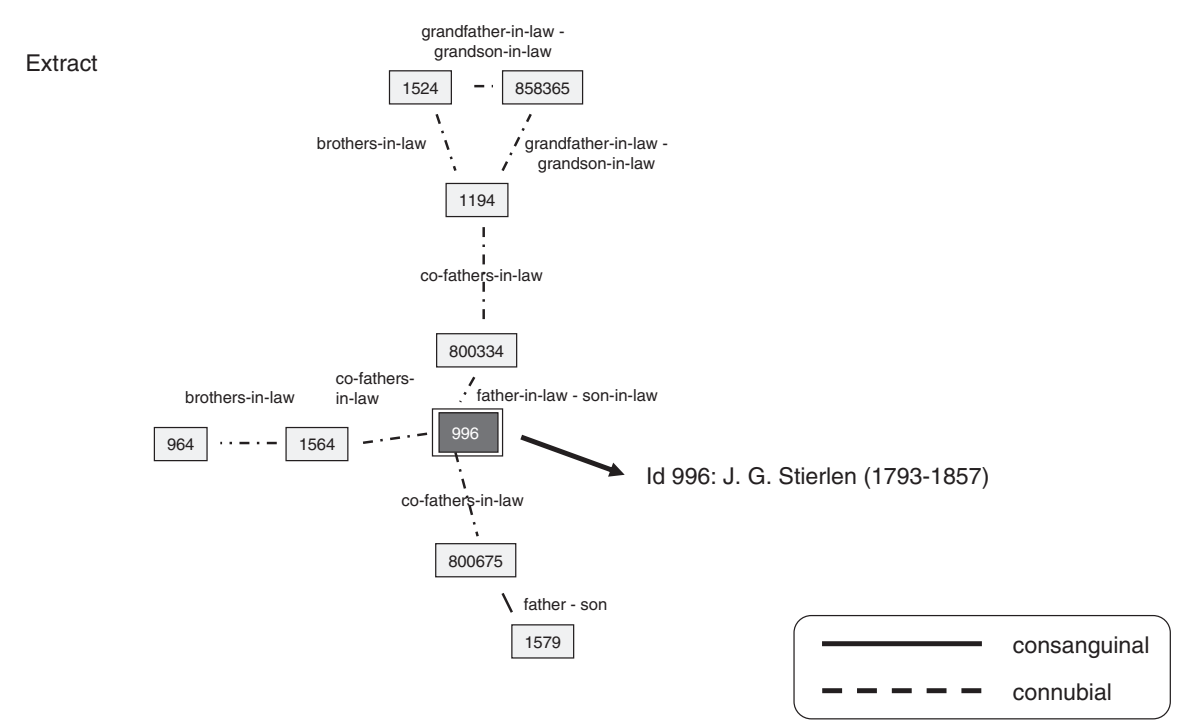

Project „Kinship and political culture in Esslingen“, Prof. Dr. C. Lipp, Göttingen University

Figure 5. Examples of a Kinship Cluster Within the City Council of Esslingen, 1803-1849

It was these honorables who served many times on the city deputation board and who were key persons in central kinship networks within the city council who were able to function as political mediators and bridge political conflicts.

When in 1846, shortly before the revolution, a sharp conflict developed between conservatives and liberals in regard to the elections for the Wuerttembergian diet and when an impeachment lanced by Democrats ended with the retreat of the elected conservative candidate, the merchant Gottlieb Stierlen (1793-1858), on whom a consensus could be built and who was able to end the conflict, neither had any recognizable outstanding public position in town nor was a noted political or ideological leader. The fact that he left no personal documents in the regional archives made his evaluation even more difficult. Only structural network analysis of the kinship network within the city council could reveal his central role to local politics and explain his election in the following year. He proved to be the key figure (see document identification number 996) in one of the most prominent kinship clusters of the city council, where he was placed at an important break point of the subnet (see Figure 5). His mother and father represented important merchant families in town, he was married to two descendants of merchant families, and he succeeded at marrying his daughters into the families of the most important entrepreneurs in town, who were all at some time members of the citizen council or the citizen deputation. The complete personal network of Stierlen was built on affinal relations; therefore he was free of tight consanguinal family obligations.

The social network emanating from the overlapping memberships (see Figure 6) of the prominent actors in the political factions from 1846 to 1848 reveals that Stierlen, through his multiconnectivity, sat on a strategic position from which he reached an enormous number of coactors. ${ }^{29} \mathrm{He}$ was placed in a tangential position at the top of the 


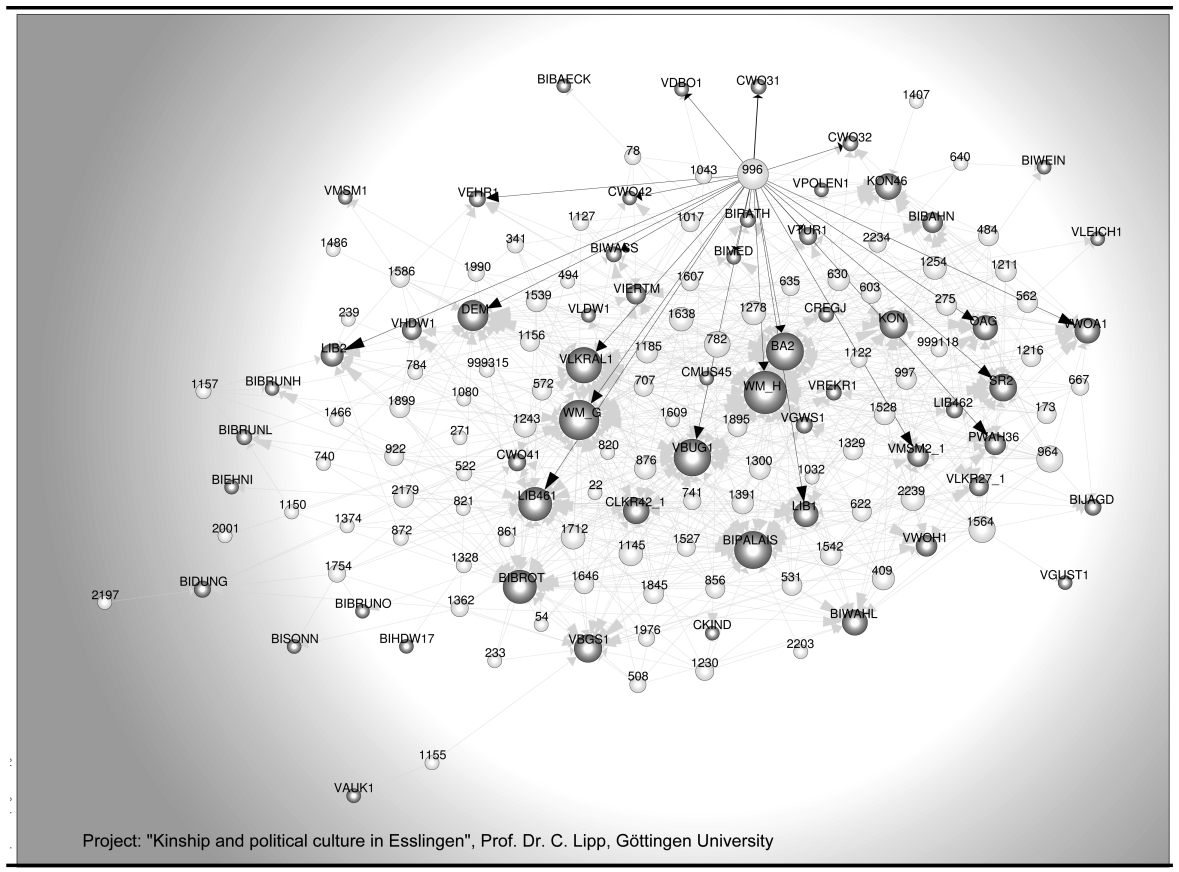

Figure 6. Strategic Actors of the Liberal Movement in Esslingen, 1848/49

network, from where he was able to connect and integrate different wings, or people of the political movement, and this empowered him to mediate between two political camps, at least for a short time at the beginning of the revolution. Network analysis showed the inner mechanisms of political configuration that at first sight were not visible to the researcher and therefore usually would have eluded interpretation.

The same is true for most types of aggregating statistics that are unable to qualify single actions or individual dynamics within complex relationships. It is the strength of structural network analysis to show strong ties as well as weak ties and the position of individuals within a group as well as the placement of certain groups building separate clusters.$^{30}$ With a network approach we tried to answer the question, how did the above-mentioned pattern of kin relationships emerge from the decisions of several hundred voters? Were there dynamics of kinship factions beyond an individual's nextof-kin that produced these results?

The project has the advantage of relying on sources that document the individual choice of each voter; that is, the names a voter gave to the officials who took note of his decision. Therefore we can reconstruct the clientele of each "candidate" in twelve local elections for the city council from 1840 to 1848 . But to be exact there were no candidates in the modern sense, because there were no parties from which to choose some potential representatives in advance. Each citizen was eligible and could be elected by his cocitizens. Since 1830 the liberal Civic Society had organized preelection meetings where proposals were made, and anonymous citizens published the names of potential candidates in the local newspaper.

Other patterns of voters' behavior could be observed, such as the mobilization along occupational lines and the influence of kinship networks within the voters' body. 
Dealing with a mostly artisanal and partially agrarian urban population in the early nineteenth century, we found that different structures of occupation played an important role in the type of clientele and the structure of kinship networks. The body of voters was clearly split between the inhabitants of the city and their kin and the vintagers living in the surrounding villages of Esslingen who were densely interlinked by marriage through a high rate of endogamy.

A closer inspection of voters' decisions in the 1840s shows that the chance to win an election in Esslingen was enhanced when the villagers mobilized their kin and voted en bloc for a person. But it cannot be said that during the 1830s and early 1840s there were acting kinship factions in the villages that rallied behind certain candidates in opposition to others. ${ }^{31}$

Obviously, the villagers had clear preferences for well-known notables, who allocated knowledge, administrational experience, and economic resources to act as representatives of the community. The concept of honorables described by Max Weber had a distinguishable impact on conservative voters' decisions; the villagers were mostly traditionalists and used to delegate responsibility to the approved honorables. ${ }^{32}$ Until 1838 no vintager had been elected and afterward, in 1840, 1842, and 1847, the villagers chose to vote for their local (magisterial) official or for innkeepers. By bourgeois standards and Wuerttembergian laws the election of the latter profession should have been avoided and was under suspicion to have been promoted by free drinks.

During the Vormärz the Esslingen vintagers did not use the power of kinship and the density of their kinship networks for their own class. Only some of the vintagers voted for their own peer group and did not pay their respect to the educated classes. When in the late 1840s people from the agrarian status group won an election, it was with the help of the inhabitants of the city and the liberals, who had formulated the claim to represent the whole community ${ }^{33}$ and who therefore proclaimed to give the agrarian groups - who until the late 1830s had had no voice in the city council-the chance for representation. In 1849 we already find three of the minor village officials in the city council. It needed the revolution of 1848-1849 to mobilize the conservative potential bred in local village kinship networks. In the city itself vintagers made up at that time 12 percent of the households, but in the community they represented nearly 24 percent of all citizens.

The situation is quite different within the artisanal group, who composed nearly 40 percent of the Esslingen population in the 1840s. A closer inspection of kinship networks within the craftsmen's guilds showed that only the traditionally rich and housebound professions ${ }^{34}$ had a close net of kin in the city, and very often their relatives were engaged in the same trade. We have some dynasties among the bakers, butchers, or the rich metal and wood professions, who even showed a coordinated voting behavior in some of the elections, but we do not have the same density of kin networks within poorer crafts. A tailor or a simple shoemaker had nothing to share with a brother or a brother-in-law. There existed of course the typical father-son succession among the artisans, but usually it was only one of the descendants who followed the father's profession while the other siblings turned to other trades or — beginning in the 1830stook on industrial work.

As we found in analyzing the elections to the city council, artisans, for example, acted far more in the context of guild membership than in the context of kin mobilization. Among the followers of artisanal candidates we find only a loose net of kinship relations (see Figure 7). To our great surprise artisanal candidates who won the elec- 


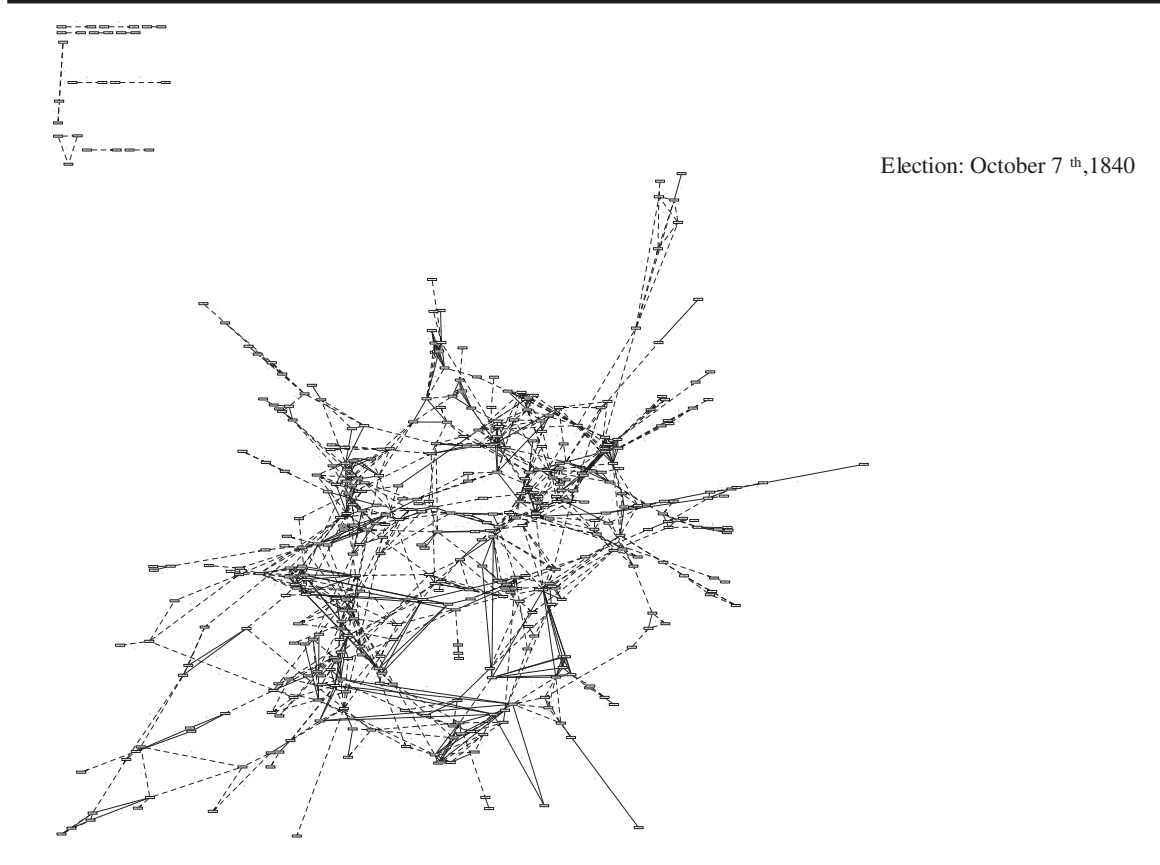

Project „Kinship and political culture in Esslingen“, Prof. Dr. C. Lipp, Göttingen University

Figure 7. Network of an Artisanal Candidate (Jeremias Schaller, Tanner)

tions mobilized only a small and scattered number of kinship networks and got the majority of their votes from guild colleagues, as a second check and look into the social structure of the voters made clear. If we look at Figure 8 we can see in contrast a very thickly woven net of kinship relations belonging mostly to the supporters of a famous local politician, Ludwig Deffner Sr., who mobilized the vintners and their multiply linked family clans.

The explanation for the thinness of the artisanal kinship networks lies in the different cultural meanings and functions of kinship and guild. Guild organization and the cultural rules that guided artisanal lifecycles had a special effect on kinship bonds and marriage chances. The idea of the "journeyman," the traveling bachelor who acquired skills and mastery in his craft before he got the chance to marry and to settle himself opened the door to an economic existence that did not exclusively rely on kinship relations but depended on corporative obligations and care. Artisan networks are, at least socially, doubly knit. Principles of artisanal socialization and organization interfered with kinship interest and sometimes overruled familial attachments, though usually sons of guild masters were privileged. The principle that guaranteed the social placement of young artisans was based on reciprocity and included (at least in theory) for each artisan who reached mastership in his craft the chance of setting up a shop and marrying. In modern urban history guilds were usually identified by constraints and restrictions regarding access to marriage and mastership. ${ }^{35}$ The prominent feature of the guild system seemed to be its resistance to in-marrying foreigners. Often ignored, however, is the fact that guilds of one city also cultivated a vivid personal exchange 


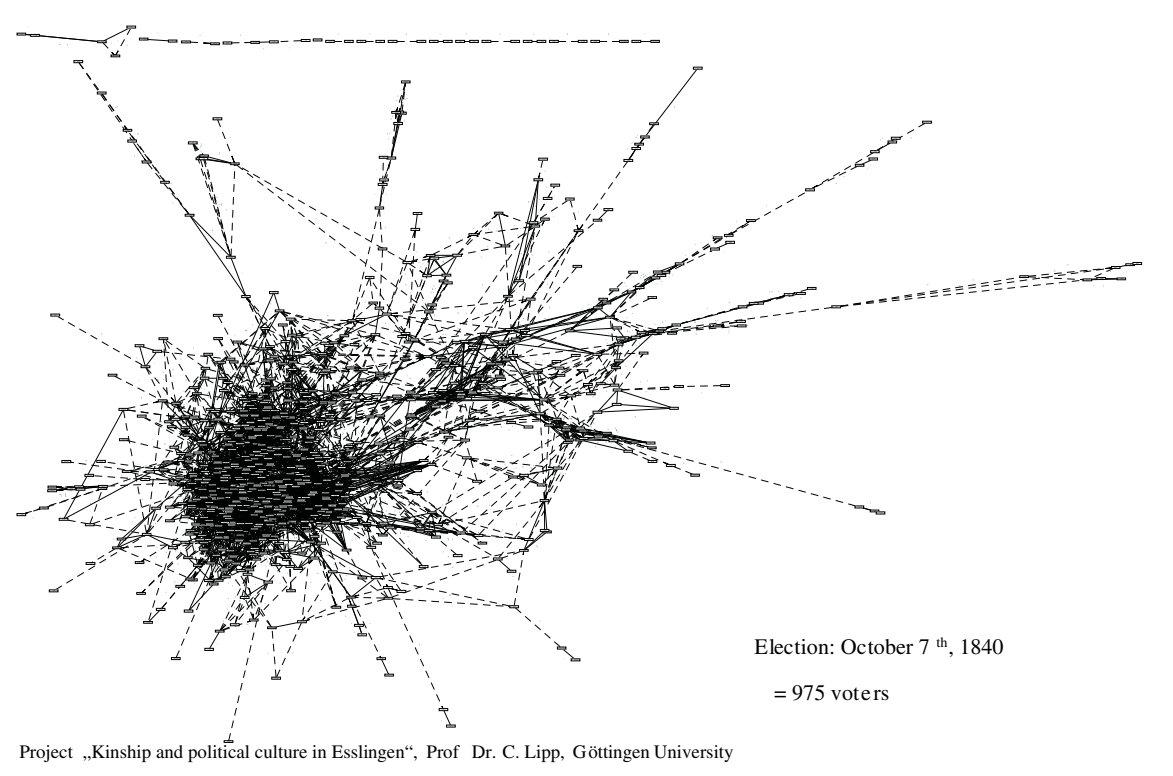

Figure 8. Network of the Entrepreneur Carl Deffner Sr., Liberal Representative of the Wuerttembergian Diet and Longtime Member of the Esslingen Council

with guilds from other cities and kept, if it was convenient, the local system for immigrant masters ${ }^{36}$ open.

Besides its controlling elements, the guild system was a system of professional reciprocity. Artisans followed occupational marriage strategies and therefore were usually more exogamous and open for people entering the guild from outside the city. ${ }^{37} \mathrm{In}$ Esslingen a third of all artisan marriages were exogamous. Though this exchange decreased when the obligation to travel ended and when this form of artisanal immigration became a harsh battlefield during the first part of the nineteenth century, the fact remains that guilds were an important medium to open kin-based closures and exclusivity. This partial exogamy logically reduced the number of direct kin that artisans had access to locally.

The internal organization of trades and guilds meant that these groups did not have to rely on kin connections only, but were integrated into a secondary net of guild relations that opened the kin system for people coming from outside. And I think this is an important and frequently misunderstood fact because both forms of social organization (guild and kinship) are thought of as equally traditional and therefore socially congruent in their effects of closure.

In contrast to the agriculturally bound population of Esslingen, artisans acted very often in the context of guild solidarity, although the guilds in the nineteenth century had lost much of their social power and were reduced to forms of educational and managerial functions. Artisans voted for their own colleagues and they acted in professional networks. Within some trades, such as baking or smithing, professional and familial relations very often overlapped, as in the example of the baker families Agner and Studenmund and the smith family of Wagner, Fallscheer demonstrates (Figures 9a and 9b). We find 


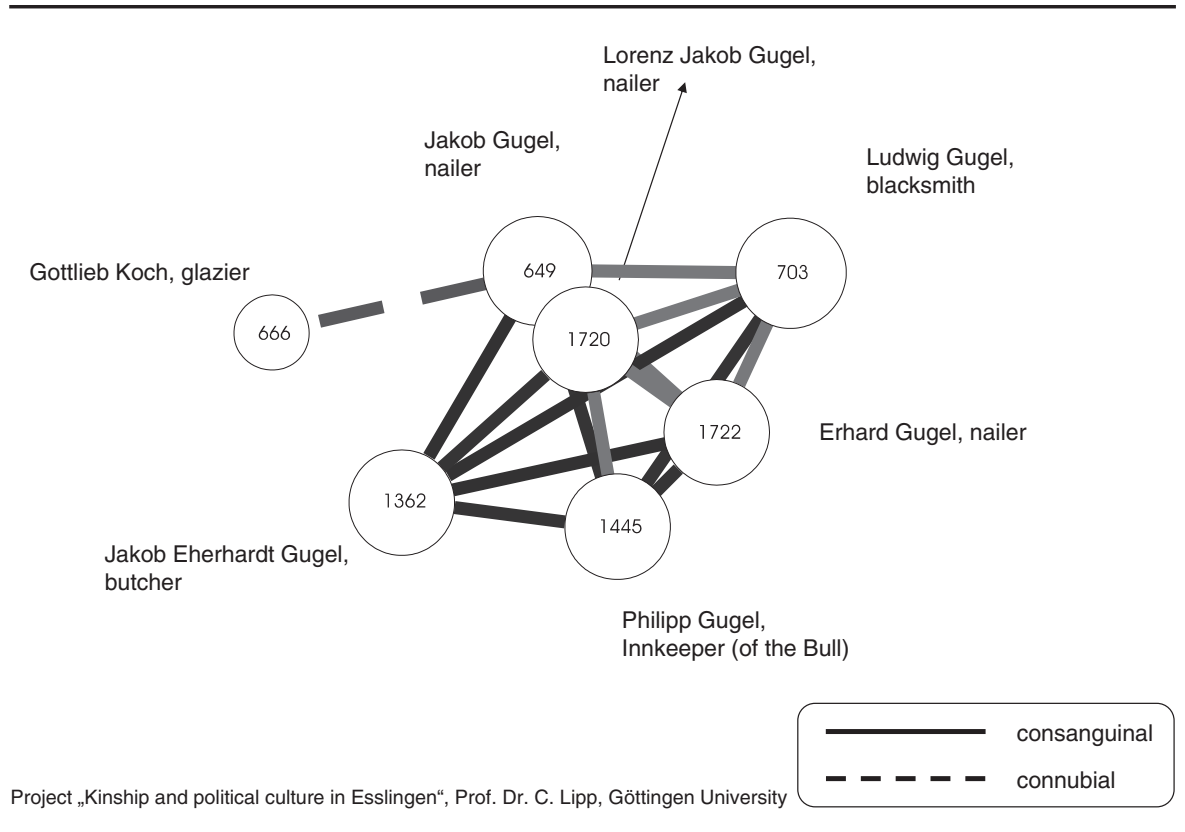

Figure 9a. Examples of Artisanal Kinship Alliances During the Elections in 1840-1848: Election 03_1841-01-20, Candidate 626: Friedrich Peterhauser, Nailer

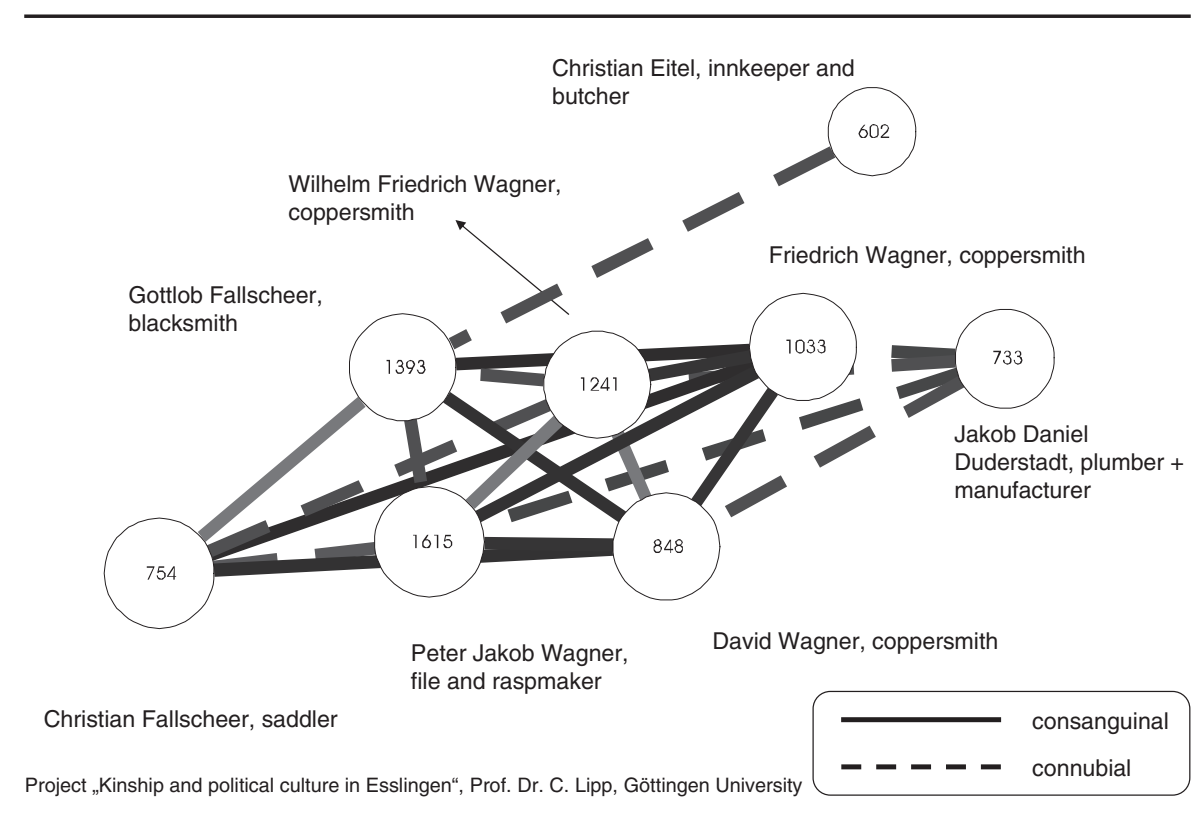

Figure 9b. Examples of Artisanal Kinship Alliances During the Elections in 1840-1848: Election 04_1842-11-02, Candidate 1483: Jakob Haug, Vintager and City Council Member 
these double-knit networks mostly within the wealthier stratum of artisans. If we look at the amount of votes we observe that kinship was not the only or dominant force to bring artisans into the city council. It was the artisanal conviction to represent the social middle class as well as the competition and political alliance of the guilds, which were at that time transformed into mere associations, with the rising bourgeois liberal movement that guaranteed artisanal success in local elections. In contrast, the classic city honorable, who was a descendant of the old elite families and who was elected in the 1840s or before, gained the mass of his votes from the vintagers, while the new rising elite of wealthy merchants and entrepreneurs could rely on both factions, artisans and vintagers, as supporters. Many of the last group and the artisans were members of the liberal movement, which organized elections and made candidate proposals. The formation of the liberal party and their election strategies to renew the council in short terms obviously enhanced the number of political decisions and increased the number of liberals in the city executive.

Nevertheless, if we look at the clientele of individual candidates we can see that the propensity of votes given by certain kinship alliances and "clans" is rather large and it increased even during the process of faction building at the dawn of the revolution. We have the impression that especially in the elections of 1848 , the number of consistently voting family alliances increased, which means traditional ties were pulled even tighter in a revolutionary and seemingly unstable situation. Kinship still shaped local politics and even liberal opponents of the old elites who criticized (in some nebulous form) "aristocratic" tendencies in the community boards used the instrument of kinship networks to succeed in the elections of 1848. For the conservatives who had been driven out of office by the protests in March, kinship even became a virulent force for their reelection. In their clientele of old local vintager and artisanal families we find the densest clusters of kin relationships.

Although we can observe that the emerging political factions and rise of parties during the Vormärz and the revolution reduced the importance of kinship ties, kinship did not easily give way to new forms of political organizations. To a certain extent political parties still remained kin based, ${ }^{38}$ and on the level of local elections kinship still was an important factor of influence.

\section{NOTES}

1. My thanks go to my coresearchers at the University of Göttingen: Astrid Reinecke, MA (Kleio-Database), Martin Irmer (SPSS), Christina Lubinski, MA (Graphs). The network analysis was done by Holger Flier, University of Cologne (working with Prof. Michael Jünger in Computational Sciences).

2. Andrejs Plakans, Kinship in the Past. An Anthropology of European Family Life 1500 1900 (Oxford, 1984).

3. It was David Schneider with his famous study on American kinship who emphasized the "meaning" of kinship in opposition to the traditional method of genealogical reconstruction practiced in social and cultural anthropology. David M. Schneider, American Kinship. A Cultural Account. (Englewood Cliffs, 1968; 2nd ed., 1980). See also David M. Schneider, A Critique of the Study of Kinship (Ann Arbor, 1984).

4. For example, Jack Goody, ed., Family and Inheritance: Rural Society in Western Europe, 1200-1800 (Cambridge, 1976); Giovanni Levi, "Family and Kin-A Few Thoughts," Journal of Family History 15 (1990): 567-578; David Warren Sabean, Property, Production and Family in 
Neckarhausen, 1700-1870 (Cambridge, 1990); Peter P. Schweitzer, ed., Dividends of Kinship: Meanings and Uses of Social Relatedness (London, 2000).

5. Carles Salazar, "Primordial Obligations: An Exploration of the Moral Basis of Western Kinship Systems." Journal of the Society for the Anthropology of Europe (2004): 16-23.

6. Graham Allan, "Sibling Solidarity," Journal of Marriage and the Family (1977): 177184, here p. 177.

7. Gottlob Friedrich Stump, Übersicht der Rechte und Pflichten des württembergischen Staats- und Gemeindebürgers. Stuttgart 1824 und Gemeindeverfassung: Verwaltungsedikt für die Gemeinden Oberämter und Stiftungen (Stuttgart, 1822).

8. David Warren Sabean, Kinship in Neckarhausen, 1700-1870. (Cambridge, 1997), 51; Barbara Rajkay, Verflechtung und Entflechtung: Sozialer Wandel in einer bikonfessionellen Stadt, Oettingen 1560-1806 (Augsburg, 1999), 55f.

9. See Carola Lipp and Lothar Krempel, "Petitions and the Social Context of Political Mobilization in the Revolution of 1848/49: A Microhistorical Actor Centered Network Analysis," in Petitions in Social History, Lex Heerma van Voss, ed.; Special Issue of International Review of Social History Supplement, No. 9 (Cambridge, 2001), 151-170; Carola Lipp, Culture et mobilisation politiques en période de révolution. L'exemple du mouvement petitionnaire d'Esslingen de 1848/49, Revue d'histoire du XIXe siècle: 1848—Nouveaux regards, (1997), 49-65.

10. Peter P. Schweitzer, ed., Dividends of Kinship: Meanings and Uses of Social Relatedness (London, 2000), introduction, 14.

11. Janet Carsten, ed., Cultures of Relatedness: New Approaches to the Study of Kinship (Cambridge, 2000), introduction, pp. 1-36.

12. Allan, Sibling Solidarity, 183.

13. See Carola Lipp, Zum Zusammenhang von lokaler Politik, Vereinswesen und Petitionsbewegung in der Revolution 1848/49: Eine Mikrostudie zu politischen Netzwerken und Formen der Massenmobilisierung in der politischen Kultur der Revolutionsjahre, Esslinger Studien, 36 (1997): 211-269; Carola Lipp: "Political and Revolutionary Culture in a German Town 1830-1850: A Prosopographical Approach" History \& Computing 12 (2000): 71-81.

14. Verwaltungsedikt für die Gemeinden, Oberämter und Stiftungen, (Stuttgart, 1822).

15. David Warren Sabean, "Social Background to Vetterleswirtschaft: Kinship in Neckarhausen," in Rudolf Vierhaus, ed., Frühe Neuzeit —frühe Moderne? (Göttingen, 1992), 11-132; Sabean, "Kinship in Neckarhausen," 1998, p. 45f.

16. Wolfgang Reinhard, Oligarchische Verflechtung und Konfession in oberdeutschen Städten, in Antoni Maczak, ed. Klientelsysteme im Europa der frühen Neuzeit, (München, 1988), 47ff; Wolfgang Schütze, Oligarchische Verflechtung und Konfession in der Reichsstadt Ravensburg, 1551-1648: Untersuchungen zur sozialen Verflechtung der politischen Führungsschichten, (Augsburg, 1981); Katarina Sieh-Burens, Oligarchie, Konfession und Politik im 16. Jahrhundert: Zur sozialen Verflechtung der Augsburger Bürgermeister und Stadtpfleger, 1518 1648 (Augsburg, 1985); Peter Steuer, Die Außenverflechtung der Augsburger Oligarchie von 1500-1620: Studien zur sozialen Verflechtung der politischen Führungsschicht der Reichstadt Augsburg, (Augsburg 1988); Jürgen Nemitz, Die direkten Steuern der Stadt Regensburg: Abgaben und Stadtverfassung vom 17. bis zum frühen 19. Jahrhundert, (München, 2000).

17. Johann Jakob Moser, Von der Reichs-Stättischen Regiments-Verfassung (Frankfurt/Leipzig, 1772), 293. See also Volker Press, Die Reichsstadt in der altständischen Gesellschaft, in Johannes Kunisch (ed.), Neue Studien zur frühneuzeitlichen Reichsgeschichte (Berlin, 1987), 9-42; see also Frank Möller, Bürgerliche Herrschaft in Augsburg 1790-1880 (München, 1998).

18. Mayors were appointed by Wuerttembergian government but chosen from three candidates who were elected by the local citizens.

19. Those unspoken rules can be found in Swiss voting rituals until nowadays, for example, in the Swiss communities ("Landsgemeinden") in Appenzell, and Außerrhoden. See 
John Bendix, Brauchtum und Politik: Die Landsgemeinde Appenzell Außenrhoden (Urnäsch, 1993), 84.

20. Pierre Bourdieu, Sozialer Raum und <Klassen >: Leçon sur la leçon (Frankfurt, 1985).

21 . The election was controlled by state officials and the decision itself was open as the voter had to name his favorite before a communal scribe.

22. Figures 3 and 4 represent only relationships; this means fifteen brother relationships do not necessarily represent thirty people, because some persons had more than one brother on the communal board.

23. Verwaltungsedikt für die Gemeinden, 1822, §6, in August Ludwig Reyscher, Sammlung der württembergischen Gesetze, vol. XV/2 (Stuttgart and Tübingen, 1845), 87.

24. See the large number of members who obviously had arranged marriages between their children (co-fathers-in-law).

25. There might be a methodological problem as D. Sabean's familial-based type of genealogical representation did not allow for tracing the complicated relationships of a whole population.

26. To explain the political structure of the city executive: The government of the free city was called "Magistracy," a name that was used as well in Wuerttemberg until 1817. The magistracy was divided into an executive inner council and an outer council. In 1817 both councils were united and were later on called City Council (Stadtrat). In the free city there was no constitutional organ for the representation of the citizens, but a radical bourgeois opposition. Wuerttemberg installed in 1817 a citizen deputation, which from 1822 forward was called Bürgerausschuss.

27. Frank Möller, Bürgerliche Herrschaft in Augsburg 1790-1880 (München, 1998), 132; Ralf Roth, Stadt und Bürgertum in Frankfurt am Main: Ein besonderer Weg von der ständischen zur modernen Bürgerschaft, 1760-1914 (München, 1996), 204.

28. The data about kinship relationships are based on the kin relationships of individual persons and not on membership. People who served in office more than once were counted as only one case.

29. For the drawing of Graph 6 I thank Lothar Krempel, MPI for Social Research, Cologne. See Carola Lipp/Lothar Krempel, "Petitions and the Social Context of Political Mobilization in the Revolution of 1848/49. A Microhistorical Actor Centered Network Analysis," in Lex Heerma van Voss, ed., Petitions in Social History. International Review of Social History Supplement 9, (Cambridge, 2001), 151-170; also Carola Lipp, Zum Zusammenhang von lokaler Politik, Vereinswesen und Petitionsbewegung in der Revolution 1848/49, in Esslinger Studien 36 (1997): 211-269.

30. Barry Wellmann and Steven D. Berkowitz, eds., Social Structures: A Network Approach (Cambridge, 1988); Patrick Doreian and Louis H. Albert, "Partitioning Political Actor Networks: Some Quantitative Tools for Analyzing Qualitative Networks," Journal of Quantitative Anthropology (1989): 279-291; Mustafa Emirbayer and Jeff Goodwin, "Network Analysis, Culture, and the Problem of Agency." American Journal of Sociology 99 (1994): 1411-1454; Bonnie H. Erickson, "Social Networks and History." Historical Methods 30 (1997): 149-157; Mark S. Granovetter, “The Strength of Weak Ties.” American Journal of Sociology 78 (1973): 1360-1380.

31. In the early nineteenth century votes were given to persons and not parties. Each voter could name a person with legal citizenship he wanted to be elected. Therefore we have a great dispersion of voters' decisions. Nevertheless there was a certain concentration of votes on people recommended by fellow citizens via newspaper or by election assemblies that mostly were organized by the liberal Civic Society beginning in the 1830 s.

32. Carola Lipp, Zur sozialen Reproduktion des Honoratiorensystems in den offenen Wahlen des Vormärz, Österreichische Zeitschrift für Geschichte, 9 (1998): 496-524.

33. Lothar Gall, "Liberalismus und 'bürgerliche Gesellschaft': Zu Charakter und Entwicklung der liberalen Bewegung in Deutschland," Historische Zeitschrift 220 (1975): 324-356. 
34. Following Mitterauer, artisans were highly mobile and only a few crafts such as brewing and baking were bound to houses. See Michael Mitterauer, "Zur familienbetrieblichen Struktur im zünftischen Handwerk," in M. Mitterauer, ed., Grundtypen alteuropäischer Sozialformen (Stuttgart, 1979), 98-122, here 114; Josef Ehmer, "Family and Business Among Master Artisans and Entrepreneurs: The Case of 19th Century Vienna." The History of the Family 6 (2001): $187-202$.

35. Katherine A. Lynch, "The European Marriage Pattern in the Cities: Variations on a Theme by Hajnal." Journal of Family History XVI (1991): 79-96, here p. 80.

36. Josef Ehmer, Soziale Traditionen in Zeiten des Wandels: Arbeiter und Handwerker im 19. Jahrhundert (Frankfurt and New York, 1994), 110f, 122ff.

37. Mitterauer, Zur familienbetrieblichen Struktur, 1979, p. 106.

38. In the liberal society of the Vormärz 43.2 percent had kin within the association; this means 1.7 relatives per person. The relationships among the Democrats reached nearly the same amount. Of the Democratic party one-third (35.5 percent) shared their membership with relatives. In contrast to them, conservatives held on to traditional structures. More than 61 percent of the members of the constitutional party had kin within the organization; this means that each constitutionalist had 3.8 relatives next to him. 